\title{
Environmental factors and childhood fever in areas of the Ouagadougou - Health and Demographic Surveillance System - Burkina Faso
}

\author{
Franklin Bouba Djourdebbé ${ }^{1}$, Stéphanie Dos Santos ${ }^{2}$, Thomas LeGrand ${ }^{3}$ and Abdramane Soura ${ }^{4}$ \\ ${ }^{1}$ PhD Candidate in Demography, University of Montreal, Email: francklin.bouba@umontreal.ca \\ ${ }^{2}$ Stéphanie Dos Santos, PhD, Researcher IRD/ISSP-Ouagadougou (Burkina Faso). Email: Stephanie.DosSantos@ird.fr \\ 3 Thomas LeGrand, PhD, Director of the Department of Demography, University of Montreal (Canada). Email: \\ tk.legrand@umontreal.ca \\ ${ }^{4}$ Abdramane Soura, PhD, Researcher ISSP-Ouagadougou (Burkina Faso). Email: asoura@issp.bf
}

\section{Problem and objectives}

Unhealthy environments are responsible for a significant proportion of morbidity and mortality worldwide. ${ }^{1,2}$ The World Health Organization estimates that the global burden of disease from environmental factors is $24 \%$, and these factors are responsible for $23 \%$ of all deaths each year. Preventing environmental risks could reduce the number of child deaths by nearly 4 million every year, mostly in developing countries. ${ }^{1}$

In African cities, infectious diseases like malaria, acute respiratory infections and diarrheal diseases contribute to a longstanding critical health situation. ${ }^{3}$ The growth of African cities in the last three decades as also led to profound changes in the local environmental context. Rapid population growth, combined with a lack of access to basic sanitation services (access to clean water, management of household waste and water, etc.) and poor housing conditions, have had a harmful effect on the health and wellbeing of urban populations. ${ }^{4}$ Understanding the links between environmental risk factors and public health is essential for the development of effective policies and programs, and ultimately to the future wellbeing of West African urban populations.

The determinants of child health are both diverse and complex. ${ }^{5-7}$ Several studies suggest that environmental factors play a decisive role in the incidence of numerous pathologies including malaria, diarrheal diseases and acute respiratory infections. ${ }^{8-11}$ Published literature on the topic reveals the importance of factors such as access to water, sanitation and hygiene for child health in cities in developing countries. ${ }^{12,13}$ Improvement in these environmental dimensions could lead to a substantial reduction in the spread of diseases. ${ }^{14}$ Other studies on urban areas, including one in Cameroon in 2007 and another in Mauritania in 2011, have brought to light other environmental factors that may affect child health, such as soil composition and the quality of the child's play area. $^{11,15}$

However, population-based studies on the relationship between immediate environment and childhood fever remain scarce and fragmented. Data from the Demographic and Health Surveys (DHS) and the Multiple Indicator Cluster Surveys (MICS), incorporate only a limited number of environmental variables (access to water, wastewater management and garbage), limiting researchers' ability to examine in detail many aspects of the environment-health relation. ${ }^{7,}{ }^{14}$ When more specific surveys exist, they tend to be based on the DHS or MICS questionnaires and also contain little detailed information on local environmental conditions. This is the case, for example, with the survey data used by Sy and colleagues in Mauritania. ${ }^{11}$

The analysis of these issues raise both conceptual and methodological/data problems, especially in regard to the population-based analysis of the causal linkages between environmental exposures and health problems among children. ${ }^{8,9}$ These difficulties arise both from the fact that the relevant dependent variables (health, fever, diarrhea, etc.) are multifactorial and that the dependent variables (access to water, sanitation, hygiene) are broad and poorly measured. 
The specific effects of the environment on health is more difficult to analyze than the socioeconomic factors that mediate these linkages, and interrelations between socioeconomic status and the local environment may be hard to take into account. ${ }^{6,16}$ Wealthy households can relocate to a residence in a healthier neighborhood. Wealthy people may also take steps to improve their surrounding environments. Better educated mothers may be more likely to proactively reduce the presence of pathogens and or their vectors in their homes by doing things such as making sure her children sleep under a mosquito net. Better educated mothers may also seek effective medical care more quickly than their less educated counterparts, when their children fall ill. Such socioeconomic factors may also affect the nutrition and vaccination statuses of the child, thereby influencing the incidence of various illnesses. Not taking these socioeconomic factors into account introduces several biases into any analyses of these issues. For instance, an effect of the environment may be highlighted, when the phenomenon is in fact a result of omitted demographic and socioeconomic variables. ${ }^{16,17}$ On the other hand, studies show that the children of rural-urban migrants are at higher risk of poor health than the children of the urban-born. Children born in slums to migrant mothers have even a higher risk of death. ${ }^{18-20}$ Neglecting the complex effects of migration can also thus bias empirical findings.

Several studies recognize the role that neighborhood environment plays in individual behavior change, even though it is not always easy to separate the effects of the neighborhood itself from the socioeconomic factors that characterize it. $^{21,22}$ The influence of local social groups, the proximity of health infrastructures and tools in a given neighborhood, as well as the perceptions of health by residents are known to be associated with neighborhood effects. ${ }^{23}$ Taking into account to possible impact of aspects of the local communities has not been not an essential part of urban health research, ${ }^{24}$ most notably in studying the links between household environmental conditions and the facilities available in the neighborhood (e.g., waste management systems or wastewater management). Many studies have focused on the poorer health conditions in informal neighborhoods and slums, ${ }^{17,25}$ which are neighborhoods characterized precisely by their lack of basic urban infrastructure (water, electricity and sanitation) ${ }^{26}$ Social cohesion - mutual trust and neighborhood cooperation - can also have beneficial effects on health and survival, and for the overall well-being of populations. ${ }^{27}$ The estimated effects of neighborhoods sometimes persist even after controlling for children's' socioeconomic factors. ${ }^{23}$

The goal of this study is to contribute to environmental health research by analyzing childhood fever in five neighborhoods on the periphery of Ouagadougou, the capital of Burkina Faso. The empirical analysis controls for demographic and socioeconomic factors of the local population - factors including the wealth of the household and of the child's mother, as well as the neighborhood of residence. A better understanding of the effect of the environment itself on health should help inform public policies aiming to reduce childhood morbidity and mortality in urban West Africa.

\section{Context, data and methods}

This analysis is based on data collected in the Ouagadougou Health and Demographic Surveillance System (Ouaga HDSS). The capital of Burkina Faso, Ouagadougou, is located in the Sahel, and in 2006, had approximately 1.5 million inhabitants ${ }^{28}$ representing about $40 \%$ of the urban population of the country. ${ }^{29}$ Due to urban population growth, the city has experienced a rapid geographical expansion, from 14 square kilometers in 1960 to 520 square kilometers in $2006 .{ }^{30}$ This unplanned and uncontrolled spread has reinforced social and spatial segregation of the urban population. ${ }^{31}$ The "unincorporated" neighborhoods (those informal settlements where land has not been officially apportioned and deeded by the government) make up a third of the total area of Ouagadougou. ${ }^{32}$ Approximately $35 \%$ of Ouagadougou's households are located in these informal areas. ${ }^{31}$ With $64 \%$ of residents born in rural areas, ${ }^{33}$ these informal neighborhoods are populated mostly by migrants and are characterized by a lack of infrastructure and access to basic urban services (water, sanitation, schools, health clinics and electricity). ${ }^{32}$

The neighborhoods in this study are located at the northern periphery of the city. The study population is comprised of 86,071 inhabitants (as of 2012) and is divided between two formal neighborhoods with access to municipal services (Kilwin and Tanghin) and three informal neighborhoods lacking such access (Polesgo, Nonghin and Nioko 2). ${ }^{34}$ Between February and August 2010, a survey on health and care-seeking behavior was conducted. This survey collected cross-sectional data on the health of 950 children under the age of 5 from 736 
households. This sample was randomly selected and is representative of all children in the Ouaga HDSS. Data was collected on episodes of fever during the two weeks preceding the survey. Baseline demographic and socioeconomic data is available for every household in the study as well each individual respondent. Information was also collected on household environment, including household waste management, management of wastewater, drinking water supply, the composition of the interior floor and use of mosquito nets.

Many studies use bivariate analyses for this type of study, failing to control for the effects of various relevant factors on the variables of interest. ${ }^{17,35}$ To address these shortcomings, we conduct multivariate analyses. Logit models are used to estimate the effects of immediate environmental factors, controlled by demographic and socio-economic variables, on the probability that a child had a reported fever in the two weeks preceding the survey. The regressions are estimated using information on 825 children under 5 years. Missing observations were withdrawn from the sample. To ensure the non-selectivity of these missing observations, model-tests were conducted and showed that the missing data were not disproportionately related to certain modalities of explanatory variables.

Moreover, if the socioeconomic variables act via proximate factors (environment), once the environmental variables are in the regression, we would expect to see effects of socioeconomic variables diminish. However, socioeconomic variables are sometimes measured with fewer errors which can have an effect on other omitted variables (access to health care, nutrition, etc.) which pass through mechanisms other than the immediate environmental context. To better understand the net effects of the environment of other potential impacts, variables were introduced by group into the models. The introduction of variables by block allows for a comparison between the different equations. First, Model 0 considered the gross effect of each independent variable. Then, Model 1 took into account all the environmental variables. Model 2 considered all demographic and socio-economic variables in addition to model 1. Model 2 takes into account the bias in the estimation of the effect of the environment. Finally, Model 3 three integrated all variables in Model 2 with the child's area of residence. This approach also helps to identify the interactions between the environment and the area of residence. To better assess the impact of variables on the probability of having a fever, predicted probabilities were calculated from Model 3, setting the value of each of the dichotomous variables to 0 and 1.

\section{References}

1. Organisation mondiale de la Santé (OMS). Prévenir la maladie grâce à un environnement sain. New York; 2007.

2. World Health Organization (WHO). Global Health risks. Mortality and burden of disease attributable to selected major risks. Geneva: WHO; 2009.

3. Organisation des Nations Unies pour I'habitat (ONU-Habitat). L'état des villes d'Afrique: Gouvernance, inégalités et marchés fonciers urbains. Naïrobi: ONU-Habitat; 2011.

4. Fonds des Nations Unies pour l'enfance (UNICEF). La situation des enfants dans le monde 2012. New York: UNICEF; 2012.

5. Lalou R, LeGrand TK. Child mortality in the urban and rural Sahel. Population 1997;9:147-168.

6. Mosley WH, Chen LC. An analytical framework for the study of child survival in developing countries. Popul Dev Rev 1984;10:25-45.

7. Montgomery MR, Hewett PC. Urban poverty and health in developing countries: Household and neighborhood effects. Demography 2005;42(3):397-425.

8. Kojima H. Déterminants environnementaux de la santé infantile et maternelle dans les pays asiatiques. In: Enfants aujourd'hui -Diversité des contextes- Pluralité des parcours: AIDELF; 2006. p. 768-778.

9. Chevalier P, Cordier S, Dab W, et al. Santé environnementale. In: Gérin M, Gosselin P, Cordier S, Viau C, Quénel $P$, Dewailly É, editors. Environnement et santé publique: fondements et pratiques. Paris: Edisem/Tec et Doc, Acton Vale; 2003. p. 59-86.

10. Merrick TW. The effect of piped water on early childhood mortality in urbain Brazil, 1970-1976. Demography 1985;22:1-23. 
11. Sy I. Gestion de l'espace urbain et morbidité des pathologies liées à l'assainissement à Rufisque (Sénégal). L'Espace géographique 2011(1):47-61.

12. Adjibade AK. L'enfant en Centrafrique: famille, santé, scolarité, travail. Paris: Karthala; 2004.

13. Woldemicael G. The effects of water supply and sanitation on childhood mortality in urban Eritrea. $J$ Biosoc Sci 2000;32(2):207-227.

14. Dégbey C, Makoutode M, Ouendo EM, Fayomi B, De Brouwer C. La qualité de l'eau de puits dans la commune d'Abomey-Calavi au Bénin. Environ Risque Sante 2008;7(4):279-83.

15. Ngwé $\mathrm{E}$, Banza-Nsungu $\mathrm{AB}$. Les déterminants socio-environnementaux de la morbidité diarrhéiques des enfants de moins 5 ans en milieu urbain au Cameroun: Les villes de Ebolowa et Maroua. Paris; 2007.

16. Kandala NB, Ji C, Stallard N, Stranges S, Cappuccio FP. Morbidity from diarrhoea, cough and fever among young children in Nigeria. Ann Trop Med Parasitol 2008;102(5):427-445.

17. Dongo K, Kouamé FK, Koné B. Analyse de la situation de l'environnement sanitaire des quartiers défavorisés dans le tissu urbain de Yopougon à Abidjan, Côte d'Ivoire. VertigO-La revue électronique en sciences de l'environnement 2008;8(3).

18. Bocquier P, Beguy D, Zulu EM, Muindi K, Konseiga A, Yé Y. Do migrant children face greater health hazards in slum settlements ? Evidence from Nairobi, Kenya. J Urban Health 2010;88(2):266-281.

19. Bocquier P, Madise NJ, Zulu EM. Is there an urban advantage in child survival in sub-Saharan Africa? Evidence from 18 countries in the 1990s. Demography 2011;48(2):531-558.

20. Konseiga A, Zulu E, Bocquier $P$, Muindi $K$, Yé Y. Assessing the effect of mother's migration on chilhood mortality in the informal settlement of Nairobi. In: Collinson MA, Adazu K, White MJ, Findley SE, editors. The Dynamics of Migrations, Health and Livelihoods Ashgate; 2009. p. 123-138.

21. Riva M, Gauvin L, Barnett TA. Toward the next generation of research into small area effects on health: a synthesis of multilevel investigations published since July 1998. J Epidemiol Community Health 2007;61(10):853-861.

22. Chaix B, Merlo J, Evans D, Leal C, Havard S. Neighbourhoods in eco-epidemiologic research: delimiting personal exposure areas. A response to Riva, Gauvin, Apparicio and Brodeur. Soc Sci Med 2009;69(9):13061310.

23. Browning CR, Cagney KA. Neighborhood structural disadvantage, collective efficacy, and self-rated physical health in an urban setting. J Health Soc Behav 2002:383-399.

24. Gauvin L, Dassa C. L'analyse multiniveaux: avancées récentes et retombées anticipées pour l'étude des inégalités sociales et de santé. Santé, Société et Solidarité 2004;3(2):187-195.

25. Fobil JN, Kraemer A, Meyer CG, May J. Neighborhood urban environmental quality conditions are likely to drive malaria and diarrhea mortality in Accra, Ghana. J Environ Public Health 2011:1-10.

26. United Nations Human Settlements Programme, (UN-Habitat). State of world's cities for all: Bridging the urban Divide. London: UN-Habitat; 2010.

27. Lochner KA, Kawachi I, Brennan RT, Buka SL. Social capital and neighborhood mortality rates in Chicago. Soc Sci Med 2003;56(8):1797-1805.

28. INSD. Recensement général de la population et de l'habitat de 2006. Rapport de synthèse des rapports d'analyse. Ouagadougou: INSD; 2009.

29. Salem G, Fournet F. Villes africaines et santé: repères et enjeux. Bull Soc Pathol Exot 2003;96(3):145-148.

30. ONU-Habitat. Profil urbain de Ouagadougou. Nairobi: ONU-Habitat; 2007.

31. Boyer F. Croissance urbaine, statut migratoire et choix résidentiels des ouagalais. Vers une insertion urbaine ségrégée ? Revue Tiers Monde 2010(1):47-64.

32. Janique E. L'accès aux services d'eau et d'assainissement dans les quartiers de Ouagadougou, Burkina Faso. Villes en développement 2006(72-73):9-10.

33. Rossier C, Soura A, Lankoande B. Migration et santé à la périphérie de Ouagadougou. In: Chaire Quételet du 16 au 18 novembre 2011. Louvain-la-Neuve (Belgique): Université Catholique de Louvain; 2012. p. 18.

34. Rossier C, Soura A, Baya B, et al. Profile: The Ouagadougou Health and Demographic Surveillance System. International Journal of Epidemiology 2012:1-9. 
35. Sy I, Tanner M, Cisse G, et al. Vulnérabilité sanitaire et environnementale dans les quartiers défavorisés de Nouakchott (Mauritanie): analyse des conditions d'émergence et de développement de maladies en milieu urbain sahélien. VertigO-la revue électronique en sciences de l'environnement 2011;11(2).

36. Dos Santos S, LeGrand TK. Accès à l'eau et mortalité des enfants à Ouagadougou (Burkina Faso). Environ Risque Sante 2007;6(5):365-371.

37. Wright CE, Alamy MEl, DuPont $\mathrm{HL}$, et al. The Role of Home Environment in Infant Diarrhea in Rural Egypt. Am J Epidemiol 1991;134(8):887-894.

38. Dos Santos S. Accès à l'eau et enjeux socio-sanitaires à Ouagadougou. Espace, Populations, Sociétés 2006(23):271-285.

39. Dos Santos S. L'accès à l'eau en Afrique subsaharienne : la mesure est-elle cohérente avec le risque sanitaire ? Environ Risque Sante 2012;11(4):282-286.

40. Prost A. L'eau et la santé. In: Gendreau F, Gubry P, Véron J, editors. Populations et environnement dans les pays du Sud. Paris: Karthala-CEPED; 1996. p. 231-251.

41. Traoré M. Analyse de la participation citoyenne autour de la gestion des déchets dans la ville de Ouagadougou (Burkina Faso); 2007.

42. Dos Santos S. Koom la viim : enjeux socio-sanitaires de la quête de l'eau à Ouagadougou (Burkina Faso). Montréal: Université de Montréal; 2005.

43. Koffi-Tessio M. Les déterminants de l'état de santé au Togo. Afr Dev Rev 2004(15):147-164.

44. Bouju J, Ouattara F. Une anthropologie politique de la fange : conceptions culturelles, pratiques sociales et enjeux institutionnels de la propreté urbaine à Ouagadougou et Bobo-Dioulassa (Burkina Faso). Marseille/Ouagadougou: Sociologie, histoire, anthropologie des dynamiques culturelles (SHADYC)/Groupe de recherche sur les initiatives locales (GRIL); 2002.

45. Dos Santos S, Rautu I, Le Hesran J-Y, et al. Environmental threats and childhood fever during the rainy season in Dakar Senegal: interest in using hierarchical models. Am J Epidemiol 2011;173(Suppl. 11):S73-S73.

46. Diallo A, Ndam NT, Moussiliou A, et al. Asymptomatic carriage of plasmodium in urban Dakar: the risk of malaria should not be underestimated. PloS one 2012;7(2):e31100.

47. Aikins MK, Pickering H, Greenwood BM. Attitudes to malaria, traditional practices and bednets (mosquito nets) as vector control measures: a comparative study in five west African countries. Am J Tropical Med Hyg 1994;97(2):81-86.

48. Pulford J, Hetzel M, Bryant M, Siba P, Mueller I. Reported reasons for not using a mosquito net when one is available: a review of the published literature. Malaria J 2011;10-83(1):1-10.

49. Bologo E, Moundain N, Randall S, Gnoumou B, Ouédraogo O. Morphologie sociale du quartier de Nioko II. Ouagadougou; 2010.

50. Peumi J-P. Facteurs environnementaux et symptômes des troubles oculaires et cutanés chez les enfants de moins de cinq ans : cas des zones de l'Observatoire de Population de Ouagadougou. Montréal: Université de Montréal; 2012.

51. Sorry I. Ouaga la belle! Gestion des déchets solides à Ouagadougou : enjeux politiques, jeux d'acteurs et inégalités environnementales. Paris: Université Paris 1 Panthéon-Sorbonne; 2013. 